\title{
Teaching English Through Games
}

\author{
Ana Bendo \\ MA, University College Bedër, Tirana- Albania \\ İsa Erbas \\ $\mathrm{PhD}$, University College Bedër, Tirana- Albania
}

\begin{abstract}
This paper aims to analyze the utilization of didactic games in ESL classes while teaching and managing the classroom, as well as strategies and tools for the game between the teacher and the students. Utilizing games in ESL course can fulfill the essential aim of teaching, which is to make students active participants in the learning process and keep them motivated. This paper focuses on analyzing the utilization of games while teaching English with the aim of actively engaging students in the learning process. This study relies on both research methods, the qualitative and quantitative one. There were interviews held with 2 English teachers and a questionnaire completed by the 144 participants. This survey was conducted in one of the high schools, in Tirana. The findings of this study bring out whether the teacher and students like or not game usage during their English classes.
\end{abstract}

Keywords: games, teaching, management, ESL course, attention, motivation

\section{Introduction}

\subsection{Background of Study}

Language is a tool of communication that is used to inform or ask other humans certain things, to express feelings, emotions, ideas or share knowledge or experiences. Definitely, language has a great importance since it serves for linguistic communication, which is a basic need for society. In addition, learning a new foreign language gives the individual an excellent opportunity in today's reality.

Having knowledge of English multiplies your chances of getting a good job not only in your country, but also even abroad in international companies. English has become the language of many fields of today's world, such as science, aviation, technology, diplomacy, tourism and many others. Learning English serves for not only work, but also it is crucial as well on socializing and entertainment, since it is also the language of many social Medias nowadays.

It has been written a lot by academics and teachers about the advantages of employing games in the language class for numerous years. According to (Ersöz., 2000) (Nga, 2003) (Andrew, 1984) (Kim, 1995) and (Yu-jing., 2000) they all affirm that utilization of games in ESL classes contributes in valuable and relevant settings for the use of the language, motivates learners to participate and collaborate with each other, since the prominence is on the message it transmits and not the structure, it can both dispute and reduce anxiety, creates opportunity of practicing the language skills, and helps learners maintain the same attempts in learning the foreign language (ErsöZ., 2000) (Kim, 1995) (Andrew, 1984) (Yu-jing., 2000) (Nga, 2003).

According to the authors mentioned in the previous paragraph, it has been acclaimed that games may provide a pleasant relax from the typical regular English lesson class. Using games after difficult test or during exhausting lessons, they can assist learners adjusting their motivation of learning or making them attentive.

\subsection{Problem Statement}

There has been a misunderstanding that English learning ought to be somber in nature. Actually, utilizing games is a significant instrument that enables language teachers to add hues to their classes by providing tests and amusement. Through games, students can become familiar with an assortment of significant aptitudes. There exist a variety of abilities 
that learners could cultivate via different games played in ESL classes, such as creativity, good sportsmanship and teamwork.

\subsection{Purpose Statement}

The principal focus of this study is on the utilization of games in English course. This study analyzes the employment of games while teaching English as a second language in an Albanian high school, and aims to discover the importance of using means of entertainment in easing the process of learning English language.

\subsection{Importance of the Study}

The significance of this study will be of great value to English language teachers to pay more attention to games, much and considerable time for exercises. Previous studies and other educational books have admitted that games are of a great value to be used with the aim of learning English language in an effective way. The findings of this study may serve as a guide to ease teachers in teaching English skills efficiently to students, and keep English students motivated and engaged in continuous studying.

\subsection{Research Questions}

The aim of this study is to answer the following questions:

- $\quad$ Are games an effective way to make an English class more attractive?

- Do games ease the process of English learning?

- Which are some of the most useful games to use in an ESL class?

- Is it difficult for the English teacher to handle games during ESL class?

\subsection{Organization of the Study}

This paper is structured into six sections. The first section offers a brief introduction to the paper. The second one encompasses the theoretical part which gives short information on what a game is and their background. It also analyzes how games should be used properly and when to use them. The third part treats the methodology used to gather the data used in this study. The fourth section analyzes the results and findings collected from the students' surveys and teachers' interviews. While the fifth section analyses the findings and interprets the results gained from the questionnaire and interviews. And finally it deals with the conclusion of this study, and a few recommendations.

\section{Literature Review}

Playing a game is considered not only as a fun activity, but it is also taken into consideration as an educative tool for learning and improving certain skills. Playing games while teaching English requires a lot of effort on the teacher's side since the teacher has to find proper games to utilize in the classroom. An educative game in an ESL classroom should meet the criteria of its purpose. Many games are found to have positive impacts on thinking and other communicative skills. Other benefits that games offer are those of social and team skills.

Learners play certain skill not only improve their knowledge but also gain other abilities, such as collaborative and team work skills. So, they benefit from a mental stimulation that games bring, as games do also require effort from the students. The students are obliged to follow the guidelines that games have and critically think to win the game. Using games in ESL classroom is seen more as an entertainment form rather as a simple form of learning. It brings a novelty to the students when learning English in a funny way so they will not feel like they are learning by-heart or being under pressure.

The results of the game playing in the end will cause students a sense of achievement and easy memorization of new English language skills. Students are more motivated when they learn by practicing and experiencing the new skills. The engagement they show in a game playing makes them eager for better results and so their motivation will be on-going.

\subsection{Definitions of games}

A "game" is considered a framed and organized play, that is usually initiated for amusement and often serving as an educational tool. There are times when they are played simply for fun, for achievement or reward, and for education purposes as well. Games can be played often in groups or teams, but they can also be played alone (UtopiaEduArt.). 
"A language-game is a philosophical concept developed by Ludwig Wittgenstein, referring to simple examples of language use and the actions into which the language is woven. Wittgenstein argued that a word or even a sentence has meaning only as a result of the 'rule' of the 'game' being played" (Wittgenstein, 1953). Language itself is involved inside an activity to gain its meaning.

Educative games are the ones that are specifically constructed with the aim of being educational and transmitting certain knowledge to the participants. They are constructed to provide people a simple and easy environment to learn about certain subjects, or assist them in improving their skills. Since educators, parents and the society are realizing the psychological need of the games, they are being used more and more in educative centers. Games are a reciprocal tool that represent not only fun and amusement, but teach many social skills, motivation, boost confidence and bring many emotions (UtopiaEduArt.).

The use of games dates from the ancient era. The oldest board game dates back to $3000 \mathrm{BC}$ in China (Nulsen, 1996). There are some ethnographers that are assured that education was the basis for building many other games. The purpose of the games were to imitate the humans' living condition, transmit knowledge to the other generations and make them ready for proper behaving in the society. Chess may be considered as a good instance of this, since as an ordinary motivational game, it had as a goal to prepare soldiers for the battlefield (Surdyk, 2008).

In the classical essay of Friedrich Schiller "Upon the Aesthetic Education of Man", play is discussed as a power of sophistication, which encourages human beings to go above their ideas and become representatives of civilized societies. He claims that "humans are only fully human when they play". "Games have long been used as means of education. Mentioning here the ancient game of chess, noblemen of the Middle Ages that was used with the purpose of learning strategies of war. Then in the early 19th century, the creation of Kindergarten by Friedrich Fröbel was made, which was based on learning the children through simple educational toys" (UtopiaEduArt.).

\subsection{Games as a teaching method}

By integrating games in their ESL classes teachers will build up an environment that fosters student's will to continuous learning. Games are highly motivating when teaching a foreign language due to the amusement that they disseminate to the learners. The students will learn better after they feel that they are making progress and so game playing will be a great source of practice for them and it will also involve even the shy students. Games are a great tool to involve all the students in practicing the skills of English language (Ersöz., 2000).

As Batteridge, Bucky and Wright have mentioned, games build an environment for relevant and purposeful communication that happens as students try to understand the game playing. By participating in game playing, learners are offered various opportunities in practicing not only, their speaking skills, but also all of them. Being immersed in utilizing the four skills of English language, the students are said to better internalize English language (Batteridge.D., 2005).

Utilizing games in class is a great way to warm up the students before the lesson starts, or to give them a break during or after the lesson when you are dealing with a hard subject. English teachers can use numerous educational games in their courses. These EFL games can be used with the aim of testing various competences of English language, such as vocabulary, grammar, listening and writing, and more other social communicative skills.

According to Gardner, whose theories demonstrate that humans possess 8 intelligences, declares that: "when delving into a new topic in school, this new topic should be approached in six various manners so to maximize the chances of being reached by all the students" (Gardner, 2006, , p. 142).

One of the ways that Gardner suggests is 'the personal way', where the final aim is to approach certain topics by using interactions or role play (Gardner, 2006, , p. 142). Additionally, Armstrong suggests as a teaching strategy the use of board games that might probably fit students that have interpersonal intelligence since they provide a great setting for collaboration within students (Armstrong, 2009).

\subsection{Choosing proper games and their importance}

In order for the game to be effective and achieve its goal, it should be specifically designed and chosen with the right properties. 
According to Tyson, games should meet some criteria in order to achieve their purposes. Some of these criteria are as follows:

* "A game must be more than just fun,

* A game should involve "friendly" competition,

${ }^{*}$ A game should keep all of the students involved and interested,

* A game should encourage students to focus on the use of language rather than on the language itself,

*A game should give students a chance to learn, practice, or review specific language material" (Tyson, 2000, p. 13).

According to Langran \& Purcell, games should be attractive for the participants and make them have fun since this will bring their attention on. Seeing that students lose interest very quickly keeping them encouraged is a crucial criterion to maintain and upgrade their learning. Another criterion that games should have is to make and help students build bonds and feel they are equal. Games must provide for the students a warm and friendly atmosphere, bringing so diversity in learning. Having an exciting environment will maintain students' interest in learning. Keeping in mind one of the reasons for learning languages that is individuals the ability to use it in real life situations, games must provide such criteria (Langran, 1994, pp. 12-14).

They can be an excellent way for putting into life this skill since games can easily be performed to enable different real-life situations. This will give the learners the chance to put their language skills into practice and improve their fluency. Practicing games in classrooms gives the students the opportunity to go beyond the frontline, gain more self-esteem, and take more responsibilities. Games should also create an area in which students become more independent and feel free to express themselves (Langran, 1994, pp. 12-14).

Another need that games should fulfill is to expose students in a variety of situations making the students ready to enjoy the experience, paying attention and being active participants. Games should also bring strong emotions to learners that mean they should feel or experience something when they join a game. Emotions, such as joy, amusement, anxiety, satisfaction, enlightenment and so on will let the students to feel easily about their learning state and this will most likely affect positively on their learning (Langran, 1994, pp. 15-19).

Games are a good tool for reluctant and shy students since they get a chance in expressing themselves in front of others. Playing a game creates a happy and social atmosphere wherever everyone feels free to enjoy it and express himself or herself as they are since the situation is not as serious and errors are not emphasized. This will boost their confidence and increase their learning (Langran, 1994, pp. 12-14).

A good game is a great strategy when teaching various subjects because most likely they will spark the interest between students. They can be used in every classroom with all students' ages and levels. A game should bring diversity and interest in learning certain topics (Sigurgeirsson., 1999).

\subsection{How to use games}

Games surely are a great fun when played, but still there should be cautions because often they may have adverse effects, for instance, if students got carried away with all the pride of the winner, might say or do something that may hurt the feeling of another one. In the moment games are employed in the lessons, the teacher must bear in mind the control of it in the proper way so not to lose direction of it. The teacher should assure that all the participants enjoy the game and have a pleasant experience, since the classroom should not become a place where students feel stucked in (Sugar, 1998, p. 16).

Another important thing to keep in mind is that not all the games are suitable for the classroom environment, or the students' ages and levels. It can be hard to decide which the right game is and that is a responsibility of the teacher. It is recommended for the teacher to pay attention to the most fundamental criteria of a game; that is a game that balanced fun, challenge and learning (Sugar, 1998, p. 16).

The teacher should be aware of the group of participants and then decide the proper game with the goals the group must be aiming. The teacher should remember not to select a complicated game that requires a lot of work since this may result in the loss of attention and interest among students, and as such it will learn them nothing. The rules of the games should be made clear since the beginning of the game, so not to cause interruption during it and the role of the teacher in this case is to observe and help where necessary, and encouraging participants (Jones, 1998, p. 14). 
With the end of the game, it is suggested to do some planned activity related to the topic of the lesson as it gives students some time to reflect upon the game and the skills and knowledge obtained from it (Langran, 1994, pp. 15-19).

It is considered crucial for teachers to understand that amplifying a game is permissible and in certain cases it may be necessary. Such as, difficult games can be simplified in order to become a challenge not only for talented students but, for less skilled ones, as well. They must fit the students' needs and their level of knowledge (Hadfield, 1990, p. 5).

\subsection{When to Use Games}

The ones who use games as a learning tool should also take into consideration the time when to use them.

According to Hadfield "games should be regarded an integral part of the language syllabus, not an amusing activity for Friday afternoon of for the end of the term" (Hadfield, 1990, p. 5). Games should be used as part of the lesson plans in order to better transmit the new skills to the students and make them active participants. For example in games 'Pictionary' and 'Where shall I go' students are able to better learn vocabulary and practice the skill of speaking as they are learning.

When teachers have to explain difficult part of grammar, they can use game playing instead of traditional teaching. Teachers may help learners comprehend particular forms of grammar by engaging them in specific games that fulfill the criteria of a conventional teaching that includes memorizing rules, repetitive drills and so on. In addition, what is crucial is that students can benefit from games their use in real life communication (Hadfield, 1990, p. 5).

Most of the teachers, trying to complete their ESL lessons often find games as a great solution not only to fill their lesson plan, but also to keep students motivated and awake during the class. The utilization of games is justified with the advantages and benefits it brings to the students. They are a great way to be used in difficult and not pleasant topics so as games can make students more active and willing to learn even the complicated topics (Kim, 1995, p. 35).

Games are mostly considered as warming-up activities to attract the student's attention, especially during free time at the end of a lecture. Games are worthy since they encourage and promote an easy learning. As Lee says: "A game should not be considered as insignificant or as an activity to fill in the free time when both the teacher and the students have nothing to do". Games should present a core element of teaching a subject in a foreign language (Kim, 1995, p. 35).

\subsection{General Benefits of Games}

Games do offer several benefits for the students. Below are mentioned some of them according to Casey Malarcher and Martha Lengeling:

\section{"Affective:}

- lowers affective filter

- encourages creative and spontaneous use of language

- $\quad$ promotes communicative competence

- motivates

- fun

\section{Cognitive:}

- reinforces

- reviews and extends

- focuses on grammar communicatively

\section{Class Dynamics:}

- $\quad$ student centered

- teacher acts only as facilitator

- builds class cohesion

- fosters whole class participation

- promotes healthy competition 


\section{Adaptability:}

- $\quad$ easily adjusted for age, level, and interests

- utilizes all four skills

- $\quad$ requires minimum preparation after development" (Malarcher Casey, 1997).

According to Lewis:

- $\quad$ "Everyone enjoys playing games since they are a lot of fun. Through games they experiment, discover and interact with the environment".

- "Games add colors to a class and boost motivation by providing a joyful encouragement to use the target language". Games do provide the stimulus to learn a language since most learners are not attentive to language learning.

- The game background brings the aimed language to life and it also is a great tool to approach to reluctant learners in a plausible manner. "Through games learning, the foreign language is made as easy as children learn their mother tongue without noticing the fact that they are studying, being so relaxed and without stressed when learning" (Lewis, 1999).

- $\quad$ Another author Chen emphasizes that games bring in focus the students and advocate communicative skills. Games build a relevant framework for language use and develop students' learning motivation. They lower anxiety and interlink many other linguistic skills. Games stimulate language utilization and inspire for creativity. They also make students active participants and create e cooperative learning atmosphere (Chen, 2005 ).

According to the author Lee Su Kim, the benefits of games are as follows:

- "Games are a welcome break from the usual routine of the language class".

- "They are motivating and challenging".

- $\quad$ "Learning a language requires a great deal of effort. Games help students to make and sustain the effort of learning".

- "Games provide language practice in the various skills- speaking, writing, listening and reading".

- "They encourage students to interact and communicate".

- "They create a meaningful context for language use" (Kim, 1995, p. 35).

\section{Methodology}

The purpose of this study is to analyze the role of games in ESL classes with the aim of upgrading students' skills of English language. This study relies also on previous researches conducted affiliated with the employment of games during English courses as a foreign language, and aims to contribute to other researches in this area.

Both methods of quantitative and qualitative have been used in order to better analyze and determine the problem and results of this research. This methodology has been used with the aim of deciding the methods, practices and the impact they had on the process.

Interviews and questionnaires in different classes were conducted for better results.

\subsection{General Overview}

The quantitative method is chosen in order to measure and determine the quantity and provide better explanations. Aliaga and Gunderson have described the quantitative research methods precisely. According to them "Quantitative research is an inquiry into a social problem, explain phenomena by gathering numerical data that are analyzed using mathematically based methods e.g. in particular statistics" (Gunderson, 2003).

Whereas qualitative method is the analysis of data collection via observation, interviews, and study of the documents in everyday framework. As Bryman and Bell (2007) have claimed qualitative research is a research strategy that shows the connection between theory and research and stresses on how these theories were generated. In this study observations, interviews with the English teachers, and book analysis were done (Bryman, 2007). 


\subsection{Participants}

This study includes only 144 participants from one of the high schools, in Tirana and 2 English teachers. Data collection was done via the interviews and surveys with the intention of gathering information on the knowledge, attitudes and beliefs of students and English teachers regarding the use of games during ESL lessons.

Through the surveys with the students' information on their attitudes against games in ESL course was gained, whereas with the interviews held with the two English teachers we tried to identify their opinions on using games while they taught English skills to their students.

\subsection{Data Collection Tools}

For this study, two different types of data collection strategies are employed: questionnaires with students and interviews with two English teachers.

\subsection{Questionnaires}

The collection of quantitative data has been made possible with the help of questionnaires that included a sample of 144 students. The questionnaire asked the students eight different questions that aimed to reveal their thoughts and attitudes on the use of games during their English classes. The questionnaires were distributed in different classes of 10th and 11th grade students, and these were completed by the students in their free time and anonymously. The questionnaires were as follows:

1. How long have you been studying English?

a) primary school b) secondary school c) high school

2. How many hours per week do you take English subject?
a) $3 \mathrm{~h} / \mathrm{w}$
b) $5 \mathrm{~h} / \mathrm{w}$
c) $6 \mathrm{~h} / \mathrm{w}$

3. Does your English teacher use games during teaching process in the class?

a) always b) usually c) sometimes $d$ ) rarely e) never

4. Do you think games are an effective learning tool?

a) yes b) not always c) no

4. Do you think games affect positively or negatively in obtaining the new skills?

a) positively b) negatively

5. Do you think using games in ESL classroom facilitates teaching-learning process of English language?

a) Yes b) no

7. Which of the used games do you find most beneficiary?

- $\quad$ "Board game

- Call My Bluff / Two Truths and A Lie

- Word Jumble Race

- Hangman

- Pictionary

- The Mime

- Hot Seat

- Where Shall I Go?

- What's My Problem?" (Lander, (2018, May 25).

8. Do you like games being part of your English class? 
a) yes b) no

\subsection{Interviews}

There were held two brief interviews with the English teachers. It contained open questions that allowed the teachers to express their ideas in a broad way and to collect as much information as possible. The interview questions were conducted related to the significance and treatment of games in English language classes. The selection of the teachers was not done randomly, since they were the English teachers of the students participating in the survey. Interview questions with the teachers are as below.

1. What is the method you use in your English class?

\section{Are games difficult to organize and manage?}

\section{Do students find games boring or attractive?}

\subsection{Limitations of the Study}

This study has some limitations. The first limitation is that the questionnaires were distributed in just one city, Tirana. Secondly, the number of the participants in the survey is not very high, only 144 participants from one high school.

As this study is based on students' responses, its validity depends on their solemnity and honesty in answering the questions. The survey was conducted in a high school in Tirana, including 10th and 11th grades. In order to achieve more precise results, a further survey with higher participation should be conducted.

\subsection{Games used for this survey}

According to Emma Lander, a qualified EFL teacher that has taught in the UK, Scandinavia and South Korea, there are some EFL games that can be used with English students to a better practice of their skills. Some of these were chosen to be used in the survey and are as below:

\section{a). Board Race}

"Board Race is a fun game that is used for revising vocabulary and grammar, whether it is words from the lesson that has been just taught or words from a lesson taught last week. It can also be used at the start of the class to get students active. It is a great way of testing what your students already know about the subject you're about to teach. This game is appropriate for all levels and ages. It is better to be played with 6 students or more. The class is split into two teams and each of them is given a colored marker. A line in the middle of the board is drawn and a topic is written at the top. The students must write as many words as required related to the topic. The teams win one point for each correctly spelled and written word" (Lander, (2018, May 25).

\section{b). Call My Bluff / Two Truths and A Lie}

"Call My Bluff is also suggested as brilliant icebreaker between students if they do not know one another. It is good for practicing speaking skill. In this game, the teacher writes 3 sentences, two of which should be lies and one should be true. Students are allowed to ask questions about each statement and then guess the truth. Then, students are paired and practice the game with their partners" (Lander, (2018, May 25).

\section{c). Word Jumble Race}

"This game is great to motivate students work in team and bring a sense of racing to the class. It fits all age groups and is recommended when practicing tenses, word order, reading, writing skills and grammar. The game needs to be planned ahead the lesson. A number of sentences are written with different colors. Then these sentences are cut up in a handful of words. These words are then given to several teams to properly be arranged and read correctly. The one that finishes first all the sentences is the winning team" (Lander, (2018, May 25).

d). Hangman

"This classic game is preferred by all students but it can get boring for them quickly. It is better used as a warm up activity before the class or when there is some time left over at the end of the lesson. A word is thought and students are required 
to guess it by saying the letters. The number of the letters is written on the board using dashes to show the number, and when the letter said by the student does not appear in the word, it is written off to the side and the image of a hanging man is drawn. It continues until the students guess the correct word (they win), or if the diagram is completed, they lose" (Lander, (2018, May 25).

\section{e). Pictionary}

"This game works well with any age group as it fosters creativity and it's a break from the usual routine of learning a new language. It helps students practice vocabulary skills and their memorization ability. A bunch of words is prepared and put in a bag. First, the class is divided into 2 teams, and the board is divided into 2 parts. A leader from each team is required to choose a word from the bag and draw the word as an image on the board. The team is encouraged to guess the word and the winning team is the one who shouts out first the correct answers. This is repeated until all the words are gone out" (Lander, (2018, May 25).

\section{f). The Mime}

"Miming is an excellent game to make students practice tenses and the verbs. It is almost suitable for any language point that the teacher wants to focus on. It works well with any age group to practice their speaking skills and to keep them more interested the miming topics should be related to any personal interest. The teacher writes out some actions and puts them in a bag. A student from each 2 teams is required to come in front of the class and select a word from the bag. Then they both are asked to mime the action and the team should guess the correct word. This is repeated until all students have mimed at least one action" (Lander, (2018, May 25).

g). Hot Seat

"Hot Seat is a game that makes possible for the students to build up their vocabulary and fosters competition in the class. It also helps to practice their speaking and listening skills, and it is suitable for any learner's level. The class is split into two teams and one student from each team is asked to sit on the 'hot seat' facing the classroom with the board behind their backs. The team then helps its members guess the word that is written on the board. The word must be described and the time is limited. It continues until each team member has described a word to the student in the "hot seat"' (Lander, (2018, May 25).

\section{h). Where Shall I Go?}

"This game is recommended for testing prepositions of movement and it is beneficial for practicing speaking and listening skill. The students should be cautious since it might be a little bit dangerous as one student in each pair will be blindfolded while the others guide them. The class should be arranged into a maze and students are paired outside the class. One of them is blindfolded and the other is guiding the partner. When a pair enters the classroom, the guiding student must use directions such as step over; go up etc. to lead their partner to the end of the maze" (Lander, (2018, May 25).

\section{i). What's My Problem?}

"This game is great to practice speaking, listening skills and giving advice. It is suggested to be played after the 'giving advice' vocabulary lesson has been covered. It works well with any age group and enhance speaking skills of students. On post-it, notes on the back of each student are written down some problems and then students are mingled and must ask for advice from others to find solutions for their problems. They ought to be able to find their problems based on the advice they receive from their peers" (Lander, (2018, May 25).

\section{Results}

In this section, the results obtained from questionnaires with students and interviews with teachers will be provided.

\subsection{An Analysis of the Life textbook}

This section will focus on a brief analysis of the Life intermediate textbook which is the book used by the students participating the questionnaire. It is written by Helen Stephenson, Paul Dummett, and John Hughes published by National Geographic Learning and Cengage Learning in 2013. The book has 12 units and respective exercises for each topic of the units. 
This book differs from other English textbooks because of its novelty. The issues are more interconnected with the real world by maximizing the opportunity for the learners to better express themselves. This book offers a range of videos, interviews and documentaries or short film features that deal with issues of the world globalization. Even though the book does not offer game plays the teachers still employ games for the many benefits they offer to the students.

Since games are prepared by the teacher themselves, they are time consuming, as they need to be organized carefully. The teachers claim that games engage students more personally and make them active participants, and that is why they use them in classes beside the book activities.

The below table provides an insight of the book units and an analysis whether the book offers respective games for each target skills.

Table 4. 1: Insights and analysis whether the book offers respective games for each skill.

\begin{tabular}{|c|c|c|}
\hline UNIT & Skill & Game \\
\hline 1.Relationships & $\begin{array}{l}\text { Vocabulary: } \\
\text { friendship, friends, nouns and } \\
\text { phrasal verbs }\end{array}$ & No game in this unit. \\
\hline 2.Storytelling & $\begin{array}{l}\text { Vocabulary/ice breaker: books and } \\
\text { films, word building, synonyms }\end{array}$ & No game in this unit. \\
\hline 3.Science and Technology & $\begin{array}{l}\text { Grammar: Future forms review; will, } \\
\text { going to, } \\
\text { Present continuous, present simple, } \\
\text { future continuous and future perfect } \\
\text { simple }\end{array}$ & No game in this unit. \\
\hline 4.Art and creativity & Vocabulary: forms of art & No game in this unit. \\
\hline 5.Development & $\begin{array}{l}\text { Grammar, speaking, listening: } \\
\text { Verbs+infinitive or-ing, forms of } \\
\text { direction }\end{array}$ & No game in this unit. \\
\hline 6.Alternative Travel & $\begin{array}{l}\text { Speaking, listening: } \\
\text { Topics: a stay at a nice hotel, } \\
\text { vacations went wrong }\end{array}$ & No game in this unit. \\
\hline 7.Natural Resources & Vocabulary, speaking and listening: & No game in this unit. \\
\hline 8.The news & Grammar, vocabulary, speaking: & No game in this unit. \\
\hline 9. Talented People & $\begin{array}{l}\text { Vocabulary: } \\
\text { describing skills, talents and } \\
\text { experiences }\end{array}$ & No game in this unit. \\
\hline 10. Customs and behaviors & $\begin{array}{l}\text { Vocabulary/speaking skills: } \\
\text { Describing traditions }\end{array}$ & No game in this unit. \\
\hline 11.Knowledge and Learning & $\begin{array}{l}\text { Grammar, writing skills, word order, } \\
\text { spelling }\end{array}$ & No game in this unit. \\
\hline
\end{tabular}




\section{The economy}

could, was able to, manage to, succeed in.

Grammar, revising vocabulary
No game in this unit.

\subsection{Observation}

The below table provides an insight of the book topics and the games played that fit each type of skill. This table has come as result of the observation conducted during game playing of the students.

Table 4.2: Insight of the book topics and the games played that fit each type of skill.

\begin{tabular}{|c|c|c|}
\hline UNIT & Skill & Game \\
\hline 1.Relationships & $\begin{array}{l}\text { Vocabulary: } \\
\text { friendship,friends, nouns } \\
\text { and phrasal verbs }\end{array}$ & $\begin{array}{l}\text { Board Game } \\
\text { Students were given the topic of Friends and were asked } \\
\text { to write as many words as possible related to Friendship } \\
\text { and friends. }\end{array}$ \\
\hline 2.Storytelling & $\begin{array}{l}\text { Vocabulary/ice breaker: } \\
\text { Books and films, } \\
\text { wordbuilding, synonyms }\end{array}$ & $\begin{array}{l}\text { Call my Bluff } \\
\text { In this game students were written } 3 \text { sentences on the } \\
\text { board about the teacher, } 2 \text { of them were lies and one was } \\
\text { the truth and they had to guess the correct sentence. } \\
\text { Students were then asked to write their own sentences and } \\
\text { divided into pairs. }\end{array}$ \\
\hline $\begin{array}{l}\text { 3.Science and } \\
\text { Technology }\end{array}$ & $\begin{array}{l}\text { Grammar: Future forms } \\
\text { review; will, going to, } \\
\text { Present continuos, present } \\
\text { simple, future continuous } \\
\text { and future perfect simple }\end{array}$ & $\begin{array}{l}\text { Word Jumble Race } \\
\text { Students were given several sentences into pieces } \\
\text { separated and put inside hats, cups and small bowls, } \\
\text { including the tenses mentioned in the target unit and they } \\
\text { were asked to put the sentences in correct order. }\end{array}$ \\
\hline $\begin{array}{l}\text { 4.Art and } \\
\text { creativity }\end{array}$ & Vocabulary: forms of art & $\begin{array}{l}\text { Pictionary } \\
\text { Students were divided into } 2 \text { teams and a leader from each } \\
\text { team was chosen to draw a word from the bag given by the } \\
\text { teacher. }\end{array}$ \\
\hline 5.Development & $\begin{array}{l}\text { Grammar, speaking, } \\
\text { listening: } \\
\text { Verbs+infinitive or-ing, } \\
\text { forms of direction }\end{array}$ & $\begin{array}{l}\text { Where Shall I go? } \\
\text { First, the class was turned into a maze, then students were } \\
\text { paired, one of them was blindofolded and guided by their } \\
\text { partner into the class to go to a place. The one who guided } \\
\text { had to use verbs with infinitive and -ing form, plus } \\
\text { directions forms. i.e. keep going right, you have to step } \\
\text { over, etc. }\end{array}$ \\
\hline $\begin{array}{l}\text { 6.Alternative } \\
\text { Travel }\end{array}$ & $\begin{array}{l}\text { Speaking, listening: } \\
\text { Topics: a stay at an ice } \\
\text { hotel, vacations went wrong }\end{array}$ & $\begin{array}{l}\text { What's my problem? } \\
\text { several students were chosen and each of them had a } \\
\text { post-it notes related to problems on the mentioned notes, } \\
\text { behind their backs and their peers tried to explain their } \\
\text { problems so they would guess the correct answer. }\end{array}$ \\
\hline $\begin{array}{l}\text { 7.Natural } \\
\text { Resources }\end{array}$ & $\begin{array}{l}\text { Vocabulary, speaking and } \\
\text { listening: }\end{array}$ & $\begin{array}{l}\text { Hot Seat } \\
\text { The class was divided into } 2 \text { teams and one student was } \\
\text { selected from each team facing the classroom with the } \\
\text { board behind them. Words on the board were written such } \\
\text { as; pollution, hydroelectric, renewable, geothermal energy } \\
\text { etc. Moreover, students from the team helped the student }\end{array}$ \\
\hline
\end{tabular}




\begin{tabular}{|c|c|c|}
\hline & & $\begin{array}{l}\text { in the hot seat by describing the word in order for him to } \\
\text { guess the correct answer. }\end{array}$ \\
\hline 8.The news & $\begin{array}{l}\text { Grammar, vocabulary, } \\
\text { speaking: }\end{array}$ & $\begin{array}{l}\text { The Mime } \\
\text { The teacher had written some actions related to the news } \\
\text { topics and put them into a bag, and students in } 2 \text { teams } \\
\text { were asked to mime the actions they would pick from the } \\
\text { bag. The team that found most mimed actions was the one } \\
\text { winning. }\end{array}$ \\
\hline $\begin{array}{l}\text { 9.Talented } \\
\text { People }\end{array}$ & $\begin{array}{l}\text { Vocabulary: } \\
\text { describing skills, talents and } \\
\text { experiences }\end{array}$ & $\begin{array}{l}\text { Hangman } \\
\text { Students were given words related to the world of } \\
\text { showbizz and famous talents and they had to guess, if } \\
\text { they said wrong letters and the man dronwed they would } \\
\text { lost the game. }\end{array}$ \\
\hline $\begin{array}{l}\text { 10.Customs and } \\
\text { behaviours }\end{array}$ & $\begin{array}{l}\text { Vocabulary/speaking skills: } \\
\text { Describing traditions }\end{array}$ & $\begin{array}{l}\text { Call my Bluff } \\
\text { Students in pair wrote } 3 \text { sentences about a particular } \\
\text { tradition, } 2 \text { of them were fake and one was right. The one } \\
\text { student from each pair had to guess the correct one. }\end{array}$ \\
\hline $\begin{array}{l}\text { 11.Knowledge } \\
\text { and Learning }\end{array}$ & $\begin{array}{l}\text { Grammar, writing skills, } \\
\text { word order, spelling } \\
\text { could, was able to, manage } \\
\text { to, succeed in. }\end{array}$ & $\begin{array}{l}\text { Word Jumble Race } \\
\text { Several sentences were cut up into a handful of words and } \\
\text { put into hats, cups and small bowls. The first team that has } \\
\text { all the sentences correctly ordered is the winning one. }\end{array}$ \\
\hline 12.The economy & $\begin{array}{l}\text { Grammar, revising } \\
\text { vocabulary }\end{array}$ & $\begin{array}{l}\text { Board Race } \\
\text { The students were divided into } 2 \text { teams, they were given } \\
\text { the topic of economy and they had to write and spell } \\
\text { correctly as many words as possible related to this topic. }\end{array}$ \\
\hline
\end{tabular}

\subsection{Survey Results}

As noted above, 144 students of in one of the high schools, in Tirana in 10th and 11th grade participated in this study. For this study, a questionnaire that consisted of eight questions was administered. This section will present the results obtained from the student questionnaire.

\section{How long have you been learning English?}

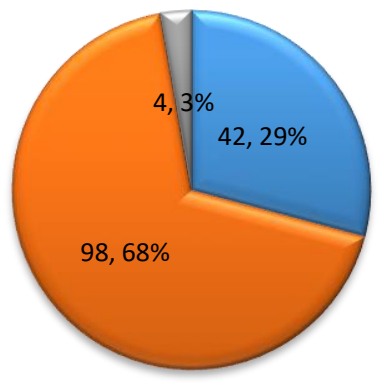

$\square$ Primary school $\square$ Secondary school $\square$ High school

\section{Chart4.1: Students period of learning English}

Regarding the first question, $98.68 \%$ of the students were studying English since secondary school, and a considerable percentage of 42.29 of students had started learning English since primary school. There was also a small percentage of 
4.3 that were taking English in high school, but they clarified that they had also attended extracurricular courses on their own.

\section{How many hours per week do you take your English subject?}

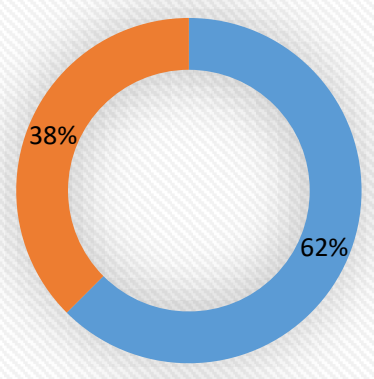

$\square$ 10th grade/ 5 hours per week

11th grade/3 hours per week

\section{Chart4. 2: Students frequency of English classes}

As shown in the chart above, students from the 10th grade take English course 5 times per week, whereas students of 11 th grade attend English class three times per week.

\section{Does your English teacher use games during teaching process in the class?}

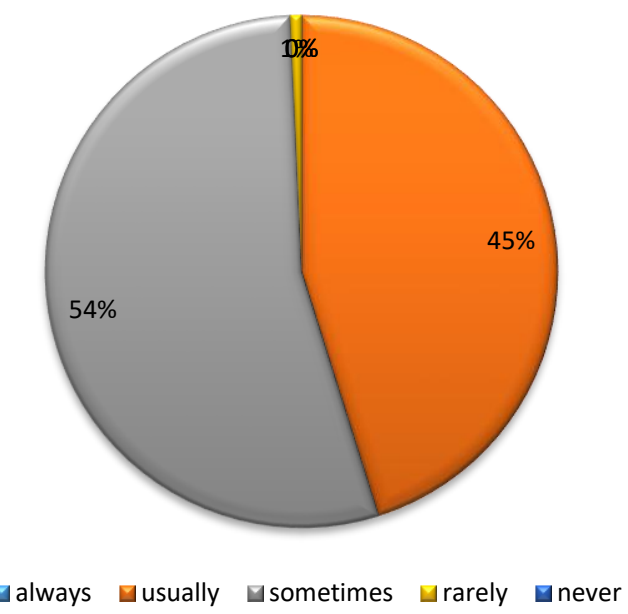

\section{Chart4.3: Game usage in class}

The chart above shows the frequency of the games used in English classes in 10th and 11th grades. Teachers used to employ games often during their English classes. 


\section{Do you think games are an effective learning tool?}

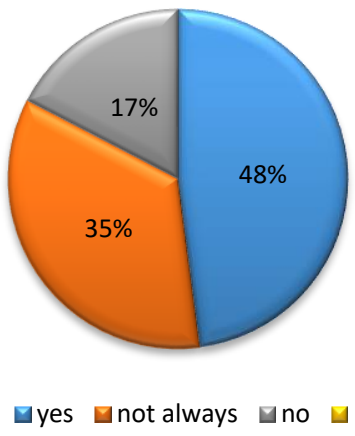

\section{Chart4.4: Opinions on game effectivity}

As the overhead graph shows, a great number of students that make up a percentage of 48 admitted that games were affective regarding their learning, whereas a $35 \%$ of the students said that not always they found games effective since they lost attention. Moreover, a small number of $17 \%$ replied games were not effective.

\section{Do you think games affect positively or negatively in obtaining the new skills?}

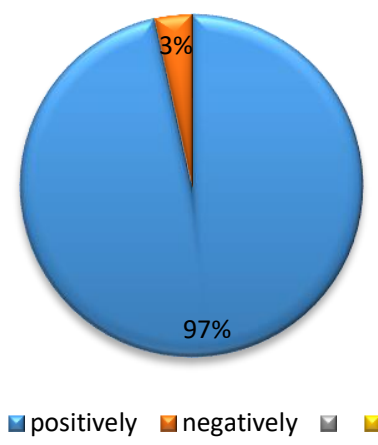

\section{Chart4.5: Positive or negative impact of games}

With regard to the above chart an abundant number of students that comprise $97 \%$ admitted that games have a positive impact in obtaining certain new skills. In so much as $3 \%$ of the students denied that games have a positive impact in acquiring the new skills. 


\section{Do games in ESL class facilitate teaching-learning process of English language?}

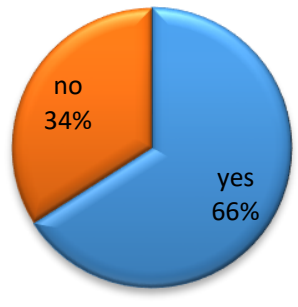

$\square$ yes $\square$ no

\section{Chart4.6: Games facilitate ESL teaching}

The overhead graph indicates the answers of the student with regard to the question whether games facilitate the process of teaching and learning. A $66 \%$ of students answered that games do facilitate this process, while $34 \%$ did not agree.

\section{Which of the used games did you find most beneficiary?
What's my problem?}

$14 \%$

Where shall I go?

$$
11 \%
$$

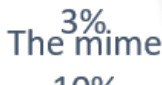

$10 \%$

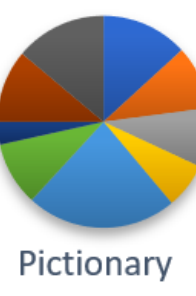

Call my B̊off

- Pictionary

- Where shall I go?
$13 \%$

Call my Bluff

$10 \%$

Word Jumble Race

$9 \%$

Hangman

$7 \%$
- Board Race

- Hangman

- Hot seat
Word Jumble Race

- The mime

What's my problem?

\section{Chart4.7: The most beneficiary game}

Pictionary was the most preferable game by the student with $23 \%$ since it helped to practice their vocabulary, $14 \%$ of the students liked 'What's my problem?' a game that helps student practice their speaking and listening skills. Also 'Board Race' was desired by a considerable number of students with $13 \%$ as it helped practice not only vocabulary, but grammar as well. 'Where shall I go, The Mime, Call my Bluff and Hangman, Word Jumble Race' were some other games played during class that had nearly the same percentage of likes. The less preferred game was 'Hangman' with only $3 \%$ of students that liked it. 


\section{Do you like games being part of your english class?}

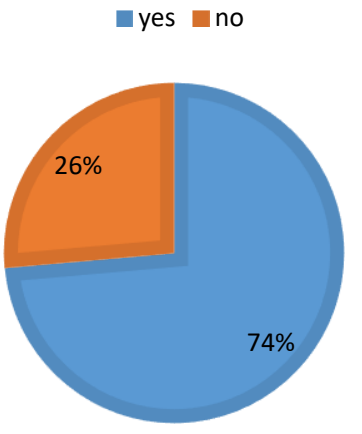

\section{Chart4.8: Attitudes against game utilization in ESL classes}

As shown in the chart a vast majority of learners that comprise $74 \%$ enjoy to have games part of their English lessons, in so much as $26 \%$ of the students were not keen on having games in their English classes.

\subsection{Interview Results}

As it is mentioned above, in this study is conducted a brief interview with two teachers of EFL from the same high school with regard to the treatment and importance of games in English language classes.

Both of the teachers agreed in using the same technique in their English classes, that was CLIL technique. CLIL stands for Content and Language Integrated Learning. This technique is used to teach and learn both content and language. Two teachers admitted that it was not a smooth task to adjust materials and that it was time consuming and not much effective for the students. It would be easier for the students if they would go gradually in learning something and so they would achieve higher grades in their exams, which was the opposite with the CLIL technique.

Surely, CLIL technique brings novelties to students by organizing different learning activities such as games, extracurricular attractive stories or worksheets. With regard to games, definitively they have a role in classroom. They are a great opportunity for engagement, examining and endeavoring things, to reach high levels in competitions and fundamentally, they bestow students with creative and critical-thinking abilities as they strive to puzzle things out, as well as, cooperative skills through simulated scenarios, and more.

Games as such have no drawbacks. They create a joyful and memorable environment. However, they are a bit stressful for the teachers to manage since they sometimes may take more than the planned time, and aside from how well a teacher plans a game, still there are some problems that may arise.

There are students who might think games are childish and a waste of time and this is clear from their facial expressions. Even though you spend a lot of time in planning the games there might be no general vibe of the class, or there are students who are really ambitious and this may cause discomfort in others. However, to have a good time with the games it is better to give a brief explanation to the students for the advantages of a specific game, such as this game is good for your speaking skills, and more.

\section{Discussion}

Learning a new language acquires a lot of hard work and effort at every moment. There should be continuous work for a long period, not only on learner's side but also from the teacher's part.

Many teachers and linguists have developed several ways and techniques in order to ease the process of learning English language. One of the techniques they have found out is the use of educative games during EFL classes. All of the authors 
that have been mentioned in this paper agree on the utilization of games in ESL classes. They discuss about the benefits they bring, but also on the right way they should be used in order to achieve their purposes.

In the case of English class, I think that various attractive techniques should be applied to make the students interested and make them acquire the new skills with ease. One of these techniques is the utilization of the games in ESL course. There is no student that does not want to have some fun and enjoyable time during their classes. To achieve this, games with educational purposes are the best way.

Games should be specifically chosen by the teacher with the intent of teaching certain skills to the students. Games ought to be meaningful in their content so to sustain the attention and enhance important skills of the learners. Previous researches have shown that games are quite effective for students as they enjoy their classes, especially for primary and secondary school learners. However, students do also enjoy games in their lessons since this makes them pay more attention to new structures of English.

At first it has been thought that education in its self should be serious and if there were games applying of any attractive techniques then it was not an education. But nowadays, most learners want education to be smooth, funny, interesting and enjoyable so it can be easy to memorize and apply in real life. That's why now a significant number of English teachers use games as part of their lesson plan. These games are carefully chosen and well-structured in order to transmit at their best the skills of speaking, writing, reading or listening. Games are a good tool to create a significant context for learning and make students collaborate with each other. Doing so, learners obtain new skills of cooperation and communication.

Based on the literature and other findings, it is important to note that games are not just fill-in time activities, but they are essential in transmitting new skills and keeping students motivated and engaged in learning.

\section{Conclusion}

The aim of this study was to understand the importance of game utilization in ESL classes as part of teaching method, by placing a great emphasis on how these games should be and their organization. Research questions of the study were: 1 . Are games an effective way to make an English class more attractive? 2. Do games ease the process of English learning? 3. Which are some of the most useful games to use in an ESL class? 4. Is it difficult for the teacher to handle games during ESL class?

This study was carried out through the employment of mixed research by applying student questionnaires to collect quantitative data and in order to collect qualitative data interviews with two teachers were hold.

The main findings of the study show that games are considered an effective tool to transmit new skills to the learners, even though they are time consuming and acquire a lot of effort by the teacher in order to be well organized and managed. Also, games are desirable by a superiority of learners. There is also a minority of students that feel inferior at strong competitors while playing games, that's why they were not enthusiastic of applying games in their classes.

Despite the lack of games in the book contents, teachers still utilize games during their ESL courses as they have seen them effective for their students.

To summarize, games are a productive technique teaching English in spite of being time consuming and tiring for the teacher.

\subsection{Recommendations}

Taking into consideration the fact that teaching a foreign language requires a lot of effort and time a significant attention should be given to it. Relying on the findings of this survey, the following recommendations can be made:

-Teachers should pay more attention to reluctant students and adapt the games based on their level.

-Teachers should be given more hours on their courses to practice game plays and be able to finish their lesson plans.

-Teachers may also sometimes organize games outside the classroom environment.

\section{Bibliography}

[1] Andrew, W. (1984). Games for Language Learning (2nd. Ed.). Cambridge University Press. 
[2] Armstrong, T. (2009). Multiple Intelligences in the Classroom . USA.: Assn for Supervision \& Curriculum; 3 edition .

[3] Batteridge.D., B. M. (2005). Games for Language Learning(3rd ed.). . New York : Cambridge University Press.

[4] Bryman, E. B. (2007). The Ethics of Management Research: An Exploratory Content Analysis.

[5] Chen, I.-J. (2005). Using games to promote communicative skills in Language learning. . TESL, 125-132.

[6] Ersöz., A. (2000). Six Games for the EFL/ESL Classroom. The Internet TESL Journal, Vol. VI, No. 6, .

[7] Gardner, H. (2006, ). The Development and Education of the Mind. . New York: : Routledge.

[8] Hadfield, J. (1990). Writing Games. England:: Longman.

[9] Gunderson, M. A. (2003). Interactive statistics,2nd edition. Pearson.

[10] Jones, A. (1998). 104 Activities That Build: self-esteem, teamwork, communication, anger,management, selfdiscovery and coping skills. . United States: Rec Room.

[11] Kim, L. S. (1995). Creative Games for the Language Class. . Forum' Vol. 33 No 1,, P35., 35.

[12] Lander, E. ((2018, May 25). , May 25). 10 Best ESL Games for English Teachers Abroad. Retrieved from Go overseas: https://www.gooverseas.com/blog/10-best-games-esl-teachers\#paragraph-item-41687---used

[13] Langran, J. \&. (1994). Language Games and Activities. Netword 2: Teaching Languages to Adults. . London.

[14] Lewis, G. (1999). Games for Children. . Oxford: Oxford University Press.

[15] Malarcher Casey, M. L. (1997, October - December). Index Cards: A Natural Resource for Teachers. Retrieved from TEFLGAMES.com: https://www.teflgames.com/why.html

[16] Nga, N. T. (2003). Learning Vocabulary Through Games. Asian EFL Journal - .

[17] Nulsen, F. (1996). .Business Simulation Games: Current Usage Levels. A ten Year Update. Developments in Business Simulation \& Experiential Exercises.

[18] Sigurgeirsson., I. S. (1999). Spectrum of Teaching Methods. Reykjavik: ÆEskan ehf.

[19] Sugar, S. (1998). Games that teach :experiential activities for reinforcing learning. San Francisco: JosseyBass/Pfeiffer.

[20] Surdyk, A. (2008). Ludology as game research in language pedagogy studies. Vilnius: Vilnius University Publishing House.

[21] Tyson, A. (2000). How to Choose Games. The internet TESL Journal, Vol. VII, No.5,, 13.

[22] UtopiaEduArt. (n.d.). Utopia Education and Art. Retrieved from Game based learning: https://www.utopiaeduart.org/courses/game-based-learning/

[23] Wittgenstein, L. (1953). Philosophical Investigations. Berlin.

[24] Yu-jing., Y. Y. (2000). Using Games in an EFL Class for Children . Daejin University ELT Research Paper. 